\title{
KARAKTERISTIK FISIKO-KIMIA GELATIN DARI SIPOU (Siphonosoma australe- australe) ASAL SULAWESI TENGGARA
}

\section{Physico-Chemical Characterization of Sipou Gelatin (Siphonosoma australe-australe) from Southeast Sulawesi}

\author{
Suwarjoyowirayatno ${ }^{*}$, Sakir2, Mita Gebriella Inthe ${ }^{1}$, Rhenislawaty ${ }^{3}$, Shalawatun Amaliah Fatimah 1 \\ 1Jurusan Teknologi Hasil Perikanan, Fakultas Perikanan dan Ilmu Kelautan Universitas Halu Oleo, Kendari, \\ Sulawesi Tenggara, Indonesia \\ 2Jurusan IImu dan Teknologi Pangan, Fakultas Pertanian Universitas Halu Oleo, Kendari, Sulawesi \\ Tenggara, Indonesia \\ 3Program Studi Kedokteran, Fakultas Kedokteran Universitas Halu Oleo, Kendari, Sulawesi Tenggara, \\ Indonesia \\ *Email korespondensi: soerdjojos@uho.ac.id (Telp: +6285241713397) \\ Diterima: 5 Oktober/ Disetujui 30 Oktober 2019
}

Cara sitasi: Suwarjoyowirayatno, Sakir, Inthe MG, Rhenislawaty, Fatimah SA. 2019. Karakteristik fisiko-kimia gelatin dari sipou (Siphonosoma australe-australe) asal Sulawesi Tenggara. Jurnal Fish Protech 2(2):280-288.

\section{ABSTRACT}

Nowadays people's concern about healthy and halal sources of gelatin is being discussed. Gelatin source development is currently underway, especially gelatin from fisheries products. The aim of this study was to determine the physical and chemical characteristics of gelatin from sipou from Southeast Sulawesi. Gelatin extraction used acid and base treatment, each treatment was three times replication. The analysis carried out by measuring the yield value, viscosity, water content, protein content, ash content, and fat content. The results of physical test of sipou gelatin showed that soaking with acid and base solution gave a yield value of $8.15 \pm 0.014 \%-9.10 \pm 0.028 \%$ and a viscosity value of $2.47 \pm 0.013 \mathrm{cP}-3.48 \pm 0.042 \mathrm{cP}$. The chemical test of sipou gelatin showed that the value of water content, protein, ash, and fat are $8.40 \pm 0.003-9.57 \pm$ $0.271 \%, 79.85 \pm 0.07-80.89 \pm 1.08,1.65 \pm 0.005-3.67 \pm 0.046$, and $1.05 \pm 0.07-2.75 \pm 0.07$ respectively.

Keywords: Acid-base processes, bean worms, gelatin, halal, sipou.

\section{ABSTRAK}

Saat ini kekhawatiran masyarakat akan sumber gelatin yang sehat dan halal ramai diperbincangkan. Pengembangan sumber gelatin saat ini sedang dilakukan, khususnya gelatin yang bersumber dari hasil perikanan. Tujuan penelitian ini adalah untuk mengetahui karakteristik fisik dan kimia gelatin dari sipou asal Sulawesi Tenggara. Ekstraksi gelatin menggunakan perlakuan asam dan basa, masing-masing perlakuan dilakukan pengulangan sebanyak tiga kali. Analisis yang dilakukan yaitu mengukur nilai rendemen, viskositas, kadar air, kadar protein, kadar abu, dan kadar lemak. Hasil analisis dibahas secara deskriptif. Hasil pengujian fisik gelatin sipou menunjukkan bahwa perendaman dengan larutan asam dan basa memberikan nilai rendemen $8,15 \pm 0,014 \%-9,10 \pm 0,028 \%$ serta nilai viskositas $2,47 \pm 0,013 \mathrm{cP}-3,48 \pm 0,042 \mathrm{cP}$. Pengujian kimia

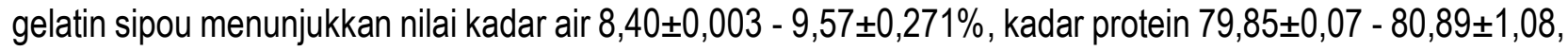

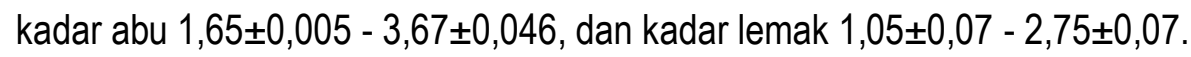

Kata kunci: Cacing kacang, gelatin, halal, proses asam basa, sipou 


\section{PENDAHULUAN}

Gelatin merupakan molekul polipeptida yang berasal dari kolagen yang merupakan protein utama penyusun jaringan hewan (kulit dan tulang). Gelatin banyak digunakan dalam industri sebagai bahan tambahan yang berfungsi sebagai stabilizer dan emulsifier sehingga dapat membuat dan mempertahankan sistem emulsi. Industri yang menggunakan gelatin meliputi industri pangan, farmasi, kosmetika dan fotografi (Rapika et al., 2016).

Gelatin masih merupakan barang impor di Indonesia, dimana Negara pengimpor utama adalah Eropa dan Amerika. Data BPS (2007) memperlihatkan pada tahun 2006 jumlah gelatin yang diimpor Indonesia adalah 3.304 ton dan angka itu diperkirakan akan terus meningkat seiring dengan pertambahan penduduk dan meningkatnya kebutuhan akan gelatin. Gelatin yang dipasarkan di Indonesia masih didominasi oleh gelatin impor. Menurut Karim (2009) gelatin impor yang dipasarkan di dunia (termasuk Indonesia) bahan bakunya diduga berasal dari kulit babi $(46 \%)$ maupun kulit sapi $(29,4 \%)$ dan tulang sapi $(23,1 \%)$ serta sumber lain $(1,5 \%)$. Penggunaan kulit dan tulang babi tidak menguntungkan bila diterapkan pada produk pangan di negara-negara yang mayoritas penduduknya beragama Islam seperti Indonesia, karena babi diharamkan untuk dimakan. Oleh karena itu, perlu dikembangkan gelatin dari sumber hewan lain (Nurimala et al., 2006).

Pengembangan sumber gelatin halal saat ini gencar dilakukan, seperti pada penelitian Suryati (2015) membuat gelatin dari ceker ayam, Rapika et al., (2016) gelatin dari kulit sapi, Astawan dan Aviana (2003) gelatin dari kulit ikan cucut, Nurimala et al., (2006) gelatin dari tulang ikan tuna, serta Khirzin (2016) gelatin dari teripang yang juga dapat berfungsi sebagai pangan fungsional antihipertensi. Salah satu organisme yang berprospek untuk dikembangkan sebagai sumber gelatin adalah Sipou (Siphonosoma australe-australe) atau peanut worm (cacing kacang).

Sipou atau peanut worm termasuk kedalam filum Sipuncula. Filum Sipuncula merupakan biota laut yang sedikit kontrovertif, dari penampilan luarnya, hewan ini mirip dengan cacing. Dalam bahasa Inggris, hewan ini bahkan kerap disebut juga dengan istilah peanut worm karena bentuknya yang menyerupai kacang tanah (Leiwakabessy et al., 2017). Beberapa literatur juga menyebut hewan ini dengan sebutan unsegmented marine worm atau dalam bahasa Indonesia disebut cacing laut tak bersegmen (Barnes, 1987). Kehadiran Sipuncula pada ekosistem pesisir memang relatif kurang dikenal jika dibandingkan dengan cacing laut Polikaeta, sebab Polikaeta telah diketahui kegunaan dan nilai ekonomisnya, yakni sebagai bioindikator pencemaran dan pakan alami tinggi protein bagi ikan atau udang (Fauchald, 1977 dalam Ager, 2004). Berbeda dengan Sipuncula, sejauh ini hanya Sipuncula jenis tertentu yang telah dimanfaatkan sebagai bahan makanan, salah satunya adalah Sipunculus nudus (Pamungkas, 2010).

Berdasarkan kandungan gizi yang baik khususnya kandungan protein yang cukup tinggi serta melihat ciri dari kulit sipou yang kenyal seperti pada kulit teripang, kulit ikan dan kulit sapi sehingga dapat digunakan sebagai penghasil gelatin, hal ini dikarenakan hewan tersebut memiliki ciri-ciri yang sesuai, dimana gelatin dapat diperoleh dari jaringan kolagen hewan yang terdapat pada kulit, jaringan ikat dan tulang. Pada prinsipnya proses produksi gelatin dapat dibagi menjadi dua macam, yaitu proses asam dan proses basa. Perbedaan keduanya terletak pada proses perendamannya. Tipe produk akhir ada dua jenis, yaitu tipe A (asam) dan tipe B (basa). Proses perbedaan metode ini akan menghasilkan perbedaan jenis kolagen yang dihasilkan. Oleh karena itu perlu dilakukan penelitian mengenai karakteristik fisika kimia gelatin yang dihasilkan sebagai sumber alternatif gelatin halal baru di Indonesia.

\section{METODE PENELITIAN}

\section{Alat dan Bahan}

Alat yang digunakan dalam penelitian ini terdiri atas timbangan digital, pisau, gelas piala, gelar ukur, 
waterbath, thermometer, desikator, oven, spatula, blender, kompor listrik, dan peralatan untuk analisis fisika kimia gelatin.

Bahan yang digunakan dalam penelitian ini adalah sipou yang diambil dari perairan pantai

\section{Rancangan Penelitian}

Pengambilan sampel penelitian ini dilakukan pada lokasi yang memiliki potensi sipou yang cukup besar. Sampel sipou kemudian dibawa ke Laboratorium untuk diekstraksi menjadi gelatin, dengan perlakuan perendaman asam (asam asetat) dan basa (Natrium hidroksida) dengan 3 kali ulangan. Selanjutnya dilakukan pengujian terhadap karakteristik fisik dan kimia gelatin yang dihasilkan. Hasil pengujian laboratorium dibahas secara deskriptif untuk menginterpretasikan data secara sistematis dan aktual.

\section{Pembuatan gelatin}

Sampel sipou (cacing kacang) dibersihkan dari kotoran dan pasir yang menempel, lalu dilakukan pengecilan ukuran. Kemudian dilakukan perendaman menggunakan asam asetat $\left(\mathrm{CH}_{3} \mathrm{COOH}\right)$ dan natrium hidroksida $(\mathrm{NaOH})$, masing-masing $3 \%$ selama 24 jam. Hasil perendaman dinetralisasi dengan aquades hingga pH 5-6. Dilakukan ekstraksi dengan perbandingan kulit dan aquades (1:3) untuk larutan asam, dan (1:2) untuk larutan basa, kemudian dipanaskan $\pm 80-90^{\circ} \mathrm{C}$ selama 5 jam. Hasil ekstraksi kemudian disaring dan dikeringkan dengan oven pada suhu $50^{\circ} \mathrm{C}$ selama $24-48$ jam. Kemudian sampel dikeluarkan dan diperolehlah gelatin tipe $A$ dan gelatin tipe $B$, yang selanjutnya akan dilakukan pengujian fisik dan kimia.

\section{Parameter uji \\ Uji Fisik \\ Rendemen (Sani et al. 2014)}

Rendemen merupakan persentase perbandingan antara berat bagian bahan yang dimanfaatkan dengan berat total bahan. Nilai rendemen ini berguna untuk mengetahui berapa banyak bahan yang bisa digunakan. Apabila nilai rendemen suatu produk atau bahan semakin tinggi, maka akan lebih banyak yang bisa digunakan. Rumus yang digunakan untuk menghitung rendemen adalah sebagai berikut:
Toronipa Kabupaten Konawe. Bahan tambahan pembuatan gelatin yaitu asam asetat $\left(\mathrm{CH}_{3} \mathrm{COOH}\right)$, natrium hidroksida $(\mathrm{NaOH})$, aquadest, etanol dan bahan untuk analisis fisika kimia gelatin.

\section{Viskositas (GMIA, 2013)}

Sampel dengan konsentrasi larutan $6.67 \%$, sebanyak $150 \mathrm{~mL}$ dengan suhu $60^{\circ} \mathrm{C}$ dimasukkan ke dalam tempat yang tersedia. Rotor dicelupkan ke dalam sampel dan dibiarkan berputar sampai jarum skala penunjukan berhenti pada skala tertentu. Skala yang terbaca menunjukkan viskositas dari sampel dengan satuan.

\section{Uji Kimia \\ Kadar Air (AOAC, 2005)}

Sampel ditimbang sebanyak $1 \mathrm{~g}$ dalam cawan. Sampel di masukkan ke dalam oven pada suhu $105^{\circ} \mathrm{C}$ selama 8 jam, kemudian didinginkan dalam desikator dan ditimbang. Kadar air dihitung dengan rumus:

$$
\text { Kadar air }(\%)=\frac{\text { Bobot awal }- \text { bobot akhir }}{\text { Bobot awal }} \times 100 \%
$$

\section{Kadar Protein (AOAC, 2005)}

Kadar protein dalam sampel dianalisis dengan metode Kjeldahl yang merupakan analisis kadar total N. Sebanyak $0.1 \mathrm{~g}$ sampel ditempatkan dalam labu kjeldahl $100 \mathrm{~mL}$ dan ditambahkan selenium dengan perbandingan $1: 1$ dan $3 \mathrm{~mL} \mathrm{H}_{2} \mathrm{SO}_{4}$ pekat. Sampel didestruksi hingga larutan menjadi jernih sekitar satu jam, lalu labu destruksi didinginkan kemudian ditambah aquadest sebanyak $50 \mathrm{ml}$ dan $20 \mathrm{~mL} \mathrm{NaOH}$ $40 \%$, kemudian didestilasi. Hasil destilasi ditampung dalam erlenmeyer yang berisi campuran $10 \mathrm{~mL}$ larutan $\mathrm{H}_{3} \mathrm{BO}_{3}$ 2\% dan 2 tetes Brom Cresol Green Methyl Red berwarna merah muda. Setelah volume destilat menjadi $10 \mathrm{~mL}$ dan berwarna hijau kebiruan, destilasi dihentikan lalu destilat dititrasi dengan $\mathrm{HCl}$ $0.1 \mathrm{~N}$ sampai merah muda. Perlakuan yang sama dilakukan juga terhadap blanko. Kadar protein dapat dihitung dengan menggunakan rumus:

$$
\text { Kadar Protein }(\mathrm{bb} \%)=5.55 \times \% \text { nitrogen }
$$

Rendemen $(\%)=\frac{\text { Produksi akhir (berat gelatin) }}{\text { Bobot awal (berat sipou) }} \times 100 \%$ 
Kadar Abu (AOAC, 2005)

Sampel ditimbang sebanyak $1 \mathrm{~g}$ dalam cawan porselen. Sampel dibakar atau diabukan dalam tanur suhu $600^{\circ} \mathrm{C}$ selama 2 jam atau sampai tidak berasap. Sampel kemudian ditimbang setelah didinginkan dalam desikator. Kadar abu dihitung dalam rumus:

$$
\text { Kadar abu (\%) }=\frac{\text { Bobot abu }}{\text { Bobot sampel }} \times 100 \%
$$

\section{HASIL DAN PEMBAHASAN}

Mutu gelatin sangat ditentukan oleh sifat fisik, kimia dan fungsionalnya. Sifat fisik gelatin dapat diketahui dengan melakukan pengujian fisik antara lain melihat nilai rendemen dan viskositas, sedangkan sifak kimia gelatin dapat diketahui dengan melakukan
Kadar Lemak (AOAC, 2005)

Sampel ditimbang sebanyak $2 \mathrm{~g}$ dan disebar diatas kapas yang beralaskan kertas saring. Kertas saring digulung hingga membentuk thimble dan dimasukkan ke dalam labu soxhlet. Sampel diekstraksi selama 6 jam dengan pelarut heksan 150 $\mathrm{mL}$. Lemak yang terekstrak dikeringkan dalam oven suhu $100^{\circ} \mathrm{C}$ selama 1 jam. Kadar lemak dihitung dengan rumus:

$$
\text { Kadar lemak }(\%)=\frac{\text { Bobot lemak }}{\text { Bobot sampel }} \times 100 \%
$$

pengujian terhadap kadar air, kadar protein, kadar abu dan kadar lemak. Hasil analisis laboratorium terhadap sifat fisiko-kimia gelatin dari sipou (Siphonosoma australe australe) asal Sulawesi Tenggara disajikan pada Tabel dibawah ini.

\begin{tabular}{|c|c|c|c|c|c|c|}
\hline \multirow{2}{*}{$\begin{array}{l}\text { Parameter Uji } \\
\text { Fisik }\end{array}$} & \multicolumn{4}{|c|}{ Sampel } & \multirow{2}{*}{$\begin{array}{c}\text { Gelatin } \\
\text { komersial } \\
\mathrm{E}^{\star \star \star}\end{array}$} & \multirow{2}{*}{$\begin{array}{c}\text { SNI } \\
06-3735 \\
(1995)\end{array}$} \\
\hline & A & B & $C^{*}$ & $D^{\star *}$ & & \\
\hline Rendemen (\%) & $9,10 \pm 0,028$ & $8,15 \pm 0,014$ & $6,61 \pm 0,52$ & $9,78^{a}$ & - & - \\
\hline Viskositas (cP) & $3,48 \pm 0,042$ & $2,47 \pm 0,013$ & 5,51 & $3,63 \pm 0,56^{b}$ & $2,0-7,5$ & $\begin{array}{l}1,5-7,5^{a} \\
2,0-7,5^{b}\end{array}$ \\
\hline
\end{tabular}

Tabel 1. Hasil karakterisasi fisik gelatin sipou dengan ekstraksi asam dan basa

Ket: A : Gelatin sipou ekstraksi asam

B : Gelatin sipou ekstraksi basa

$C^{*}:$ Gelatin kulit ikan tenggiri (Gunawan et al., 2017)

$D^{* *}$ : aGelatin kulit sapi (Sasmitaloka et al., 2017), ${ }^{b}$ Gelatin kulit kerbau (Arsyanti et al., 2018)

$\mathrm{E}^{\star *}:$ Gelatin standar (Tourtellote, 1980)

SNI : aAsam, ${ }^{\mathrm{B} B a s a}$

\section{Rendemen}

Salah satu parameter penting dalam proses pembuatan gelatin adalah rendemen. Tinggi rendahnya rendemen dipengaruhi oleh proses dan bahan ekstraksi yang digunakan. Rendemen yang tinggi memperlihatkan bahwa perlakuan ekstraksi gelatin yang dilakukan semakin efektif dan efisien. Berdasarkan data Tabel 1, terlihat bahwa nilai rendemen dengan perlakuan asam lebih tinggi $(9,10 \%)$ dibandingkan dengan perlakuan basa $(8,10 \%)$. Hal ini disebabkan karena larutan asam dalam mengurai bahan lebih efektif, dikarenakan ion
$\mathrm{H}^{+}$pada larutan asam dapat merubah rantai triple helix sipou dari struktur kompleks menjadi sederhana (rantai tunggal), sedangkan larutan basa (ion $\mathrm{OH}^{-}$) hanya mampu mengubah sampai ke rantai ganda, sehingga terdapat kekurangan dalam menghidrolisis protein kolagen sipou menjadi gelatin. Hal ini sesuai dengan pernyataan Nurilmala (2004) bahwa semakin rendah pH larutan perendaman (yang berarti semakin besar konsentrasi asamnya), maka rendemen semakin tinggi. Hal ini diduga karena ion $\mathrm{H}+$ yang menghidrolisis kolagen lebih banyak, tetapi kecenderungan ini mencapai batas maksimal apabila 
ion $\mathrm{H}+$ yang berlebih mendenaturasi kolagen yang terhidrolisis. Lebih lanjut Sasmitaloka et al. (2017) menyatakan bahwa pada waktu yang sama jumlah kolagen yang dihidrolisis oleh larutan asam lebih banyak daripada larutan basa. Sehingga pada waktu perendaman yang sama, rendemen gelatin menggunakan pelarut $\mathrm{HCl} 1 \%$ lebih besar dibandingkan pelarut $\mathrm{NaOH} 1 \%$.

Nilai rendemen hasil pengujian sipou lebih tinggi jika dibandingkan dengan rendemen gelatin kulit ikan tenggiri 6,61\% (Gunawan et al., 2017), kulit ikan patin 6,14\% (Pertiwi et al., 2018), dan serupa dengan rendemen gelatin dari kulit sapi 9,78 (Sasmitaloka et al., 2017), gelatin dari tulang ikan tuna 3,8-11,4\% (Nurilmala, 2006) dan lebih rendah jika dibandingkan dengan gelatin dari kulit ikan kakap merah 11,0416,8\% (Trilaksani et al., 2012). Karim dan Bhat (2009) menyatakan bahwa tingkat konversi kolagen menjadi gelatin tergantung pada proses pengolahan, waktu ekstraksi, suhu, $\mathrm{pH}$, kondisi pretreatment, karakteristik bahan baku, dan metode penanganan awal bahan baku.

\section{Viskositas}

Viskositas merupakan parameter penting dalam mengetahui tingkat kualitas suatu gelatin. Viskositas adalah daya aliran molekul dalam suatu larutan. System koloid dalam larutan dapat meningkat dengan cara mengentalkan cairan sehingga terjadi absorbs dan perkembangan koloid (Glicksman, 1969). Tabel 1 menunjukkan bahwa nilai viskositas gelatin sipou dengan perlakuan asam (3,48 cP) lebih tinggi jika dibandingkan dengan perlakuan basa $(2,47 \mathrm{cP})$. Hal ini disebabkan karena perlakuan perrendaman larutan asam bekerja lebih baik dalam mengurai kolagen sehingga asam amino yang terbentuk cukup panjang dan berat molekul yang tinggi sehingga viskositasnya menjadi tinggi. Menurut Trilaksani et al. (2012) viskositas gelatin dipengaruhi oleh $\mathrm{pH}$ gelatin, temperatur, konsetrasi gelatin dan penambahan elektrolit lain dalam larutan gelatin.

Hasil pengujian ini masih tergolong dalam standar viskositas gelatin menurut Tourtellote (1980) yaitu 2,0-7,5 cP, sedangkan menurut SNI 1995 viskositas gelatin menggunakan pelarut asam yaitu 1,5-7,5 cP dan pelarut basa 2,0-7,5 cP. Nilai viskositas yang dihasilkan tidak jauh berbeda dengan nilai viskosistas untuk beberapa sampel yang berbeda. Nilai viskositas gelatin kulit ikan tenggiri yaitu $5,51 \mathrm{cP}$ (Gunawan et al., 2017), gelatin tulang ikan patin 3,83 CP (Pertiwi et al., 2018), gelatin tulang ikan lele $(3,83$ cP), gelatin kulit sapi 3,63 cP (Arsyanti et al., 2018) dan nilai viskositas gelatin kulit kerbau dengan perlakuan asam 7,75 cP dan basa 6,25 cP (Sasmitaloka et al., 2017) serta lebih rendah jika dibandingkan dengan gelatin tulang ikan nila 12,17 cP (Wijaya et al., 2015).

Tabel 2. Hasil karakterisasi kimia gelatin sipou dengan ekstraksi asam dan basa

\begin{tabular}{lcccccc}
\hline \multirow{2}{*}{$\begin{array}{c}\text { Parameter Uji } \\
\text { Kimia }\end{array}$} & \multicolumn{4}{c}{ Sampel } & & \multicolumn{2}{c}{$\begin{array}{c}\text { Gelatin } \\
\text { komersial } \\
\mathbf{E}^{* * *}\end{array}$} & $\begin{array}{c}\text { SNI } \\
\mathbf{0 6}-\mathbf{3 7 3 5} \\
(\mathbf{1 9 9 5 )}\end{array}$ \\
\cline { 2 - 6 } & $\mathbf{A}$ & $\mathbf{B}$ & $\mathbf{C}^{*}$ & $\mathbf{D}^{* *}$ & 12,21 & Maks 16 \\
\hline Kadar air (\%) & $8,40 \pm 0,003$ & $9,57 \pm 0,271$ & 10,19 & $42,93 \pm 0,49$ & \\
Kadar Protein (\%) & $79,85 \pm 0,07$ & $80,89 \pm 1,08$ & 88,88 & $62,01 \pm 0,59$ & 85,99 & - \\
Kadar Abu (\%) & $1,65 \pm 0,005$ & $3,67 \pm 0,046$ & 0,4 & $0,17 \pm 0,02$ & 1,66 & Maks 3,25 \\
Kadar Lemak (\%) & $1,05 \pm 0,07$ & $2,75 \pm 0,07$ & 0,33 & $0,86 \pm 0,09$ & 0,23 & - \\
\hline
\end{tabular}

Ket: A : Gelatin sipou ekstraksi asam

B : Gelatin sipou ekstraksi basa

$C^{*}$ : Gelatin kulit ikan kakap (Trilaksani et al., 2012)

$D^{* *}$ : Gelatin kulit sapi (Sasmitaloka et al., 2017)

$\mathrm{E}^{\star \star *}$ : Gelatin komersial (Nurilmala, 2004) 


\section{Kadar air}

Pengujian kadar air bertujuan untuk melihat kandungan air yang terdapat pada gelatin sipou. Kandungan kadar air akan mempengaruhi daya simpan gelatin yang dihasilkan. Hal ini berkaitan erat dengan aktivitas mikroorganisme yang terjadi saat gelatin tersebut disimpan. Berdasarkan hasil uji kadar air (Tabel 2) memperlihatkan nilai kadar air gelatin dengan perendaman larutan asam sebesar $8,4 \%$ dan larutan basa $9,57 \%$. Kadar air yang dihasilkan masih memenuhi standar yang disyaratkan SNI 1995 yaitu maksimum 16\% (BSN, 1995) dan gelatin komersial $12,21 \%$ (Nurilmala, 2004), serta standar FAO JECFA (2003) yaitu maksimum 18\%.

Hasil pengujian kadar air sipou tidak jauh berbeda dengan kadar air gelatin kulit ikan kakap sebesar 10,19\% (Trilaksani et al., 2012), kulit ikan tenggiri 7,69 $\pm 0,12 \%$ (Gunawan et al., 2017), tulang ikan patin 7,72\% (Pertiwi et al., 2018), dan jauh lebih rendah jika dibandingkan dengan kadar air gelatin kulit sapi sebesar 42,93\% (Sasmitaloka et al., 2017). Proses pengeringan yang berbeda akan mempengaruhi kandungan air pada gelatin yang dihasilkan. Pengeringan gelatin sipou menggunakan oven, sedangkan pengeringan komersial menggunakan vaccum evaporator dan freeze dryer.

\section{Kadar protein}

Hasil pengujian kadar protein gelatin berbahan dasar sipou menunjukkan nilai yang cukup tinggi. Perlakuan perendaman asam memberikan nilai $79,85 \%$ dan perendaman basa $80,89 \%$. Nilai kadar protein ini menghampiri nilai protein gelatin komersil sebesar $85,99 \%$ (Nurilmala, 2004). Tingginya kadar protein dari gelatin sipou dapat bersumber dari bahan baku yang digunakan. Cacing sipou memiliki kandungan protein 17,288\% (Rahayu et al., 2019), 16,88 - 17,13\% (Silaban dan Nanlohy, 2011), kandungan protein sipou segar $10,11 \pm 0,80 \%$ dan sipou dengan freese dry $56,35 \%$.

Nilai kandungan protein gelatin sipou ini lebih tinggi jika dibandingkan dengan gelatin tulang ikan patin 58,70\% (Pertiwi et al., 2018), tulang ikan lele $64,76 \%$ (Permata et al., 2016) dan lebih rendah jika dibandingkan dengan kulit ikan tenggiri 86,78 $\pm 0,07 \%$ (Gunawan et al., 2017), gelatin ikan nilai 84,37 $\pm 0,03 \%$ - 2,073 $\pm 0,02 \%$ (Wijaya et al., 2015). Menurut Trilaksani et al. (2012) kadar protein gelatin dipengaruhi oleh proses perendaman kulit dan proses ekstraksi. Proses perendaman terjadi reaksi pemutusan ikatan hidrogen dan pembukaan struktur koil kolagen yang terjadi secara optimum sehingga jumlah protein yang terekstrak pada suhu yang tepat menjadi banyak.

\section{Kadar abu}

Pengujian kadar abu gelatin sipou memperlihatkan perlakuan dengan perendaman asam sebesar $1,65 \pm 0,005 \%$ dan perendaman basa sebesar $3,67 \pm 0,046 \%$. Nilai kadar abu perendaman asam masih memenuhi standar SNI 1995, sedangkan nilai kadar abu perendaman basa melebihi batas maksimum yang dipersyaratkan. Nilai standar kadar abu menurut SNI 06-3735-1995 yaitu maksimum $3,25 \%$ (BSN, 1995), dan kadar abu gelatin komersial sebesar 1,66\% (Nurilmala, 2004). Tinggi rendahnya kadar abu gelatin sipou disebabkan oleh pengaruh bahan pelarut yang digunakan. Penggunaan larutan asam menghasilkan proses demineralisasi yang lebih baik dibandingkan dengan penggunaan larutan basa. Kadar abu yang dihasilkan menunjukkan kemurnian gelatin yang dihasilkan. Menurut Duconseille et al., (2015) adar abu yang tinggi disebabkan proses demineralisasi yang belum sempurna.

Nilai kadar abu gelatin sipou lebih tinggi jika dibandingkan dengan gelatin ikan tenggiri $0,58 \pm 0,13 \%$ (Gunawan et al., 2017), tulang ikan patin 0,38\% (Pertiwi et al., 2018), gelatin kulit kambing 1,34 $\pm 0,94$ $3,10 \pm 0,66$ (Said et al., 2011) dan lebih rendah dibandingkan dengan tulang ikan lele 13,37\% (Permata et al., 2016) serta tulang ikan pari $13,70 \%$ (Sopian, 2002).

\section{Kadar lemak}

Hasil pengujian kadar lemak gelatin sipou dengan perendaman asam sebesar $1,05 \pm 0,07 \%$ dan perendaman basa sebesar $2,75 \pm 0,07 \%$. Nilai ini jauh lebih tinggi jika dibandingkan dengan gelatin komersial 
sebesar $0,86 \pm 0,09 \%$. Perbedaan nilai ini disebabkan karena pengaruh konsentrasi pelarut asam dan basa yang belum optimal dalam mendegradasi lemak pada gelatin sipou. Sasmitaloka et al. (2017) menyatakan bahwa gelatin bermutu tinggi diharapkan memiliki kandungan lemak rendah bahkan tidak mengandung lemak. Kadar lemak gelatin yang direndam $\mathrm{NaOH} 1 \%$ berbeda nyata dengan pelarut asam. Yang et al., (2008), hal ini disebabkan karena pelarut basa hanya bisa menghidrolisis triple helix menjadi double helix, sehingga tingkat exstruction lemak dalam sel belum optimal.

Nilai kadar lemak gelatin sipou lebih rendah dari kadar lemak ikan kakap 0,33\% (Trilaksani et al., 2012), kulit ikan tenggiri $0,71 \pm 0,07 \%$ (Gunawan et al., 2017), gelatin kulit sapi 0,86 $\pm 0,09 \%$ (Sasmitaloka et al., 2017), dan serupa dengan nilai gelatin ikan $0,64 \pm 0,03 \%-2,073 \pm 0,02 \%$ (Wijaya et al., 2015), tulang ikan patin 2,79\% (Pertiwi et al., 2018),

\section{KESIMPULAN}

Kesimpulan dari hasil penelitian ini yaitu terdapat perbedaan nilai fisik dan kimia gelatin sipou yang diekstraksi menggunakan larutan asam dan basa. Penggunaan larutan asam (asam asetat) memberikan nilai yang lebih baik dibandingkan dengan penggunaan larutan basa (natrium hidroksida). Pengembangan penggunaan larutan asam yang berbeda sangat diperlukan untuk untuk melihat efektivitas proses ekstraksi ini.

\section{UCAPAN TERIMAKASIH}

Ucapan terimakasih disampaikan kepada Universitas Halu Oleo Kendari terkhusus pada Lembaga Penelitan dan Pengabdian Kepada Masyarakat (LPPM UHO) yang telah memberikan alokasi dana untuk pelaksanaan kegiatan penelitian ini.

\section{DAFTAR PUSTAKA}

Ager 0. 2004. Aquaculture, the marine life information. Network for Britain and Ireland.
[AOAC] Association Official Analitycal Chemistry. 2005. Official Method of Analysis. $18^{\text {th }}$ Ed. Maryland (US): AOAC International.

Arsyanti L, Erwanto Y, Rohman A, Pranoto Y. 2018. Chemical composition and characterization of skin gelatin from buffalo (Bubalus bubalis). International Food Research Journal 25(3): 1095-1099.

Astawan M dan Aviana T. 2003. Pengaruh jenis larutan perendam serta metode pengeringan terhadap slfat fisik, kimia, dan fungsional gelatin dari kulit cucut. Jurnal Teknol dan Industri Pangan 16 (1): 7-13.

Barnes RD. 1987. Invertebrate Zoology. Edisi ke-5. Saunders College Publishing, Orlando.

[BPS] Badan Pusat Statistik. 2007. Data Ekspor Impor Indonesia. BPS. Jakarta.

[BSN]. Badan Standarisasi Nasional. 1995. Standar Nasional Indonesia. 063735.1995. Mutu dan Cara Uji Gelatin. Jakarta.

Duconseille, A., T. Astruc, N. Quintana, F. Meersman, and V. E. SanteLhoutellier. 2015. Gelatin structure and composition linked to hard capsule dissolution: A review. J. Food Hydrocoll. 43: 360-376.

[JECFA]. Joint Expert Communittee on Food Additives. 2003. Edible Gelatin. Di dalam Compendium of Additive Specications. Volume 1. Italy: Rome.

Glicksman M. 1969. Gum Technology in The Food Industry. Academic Press. New York.

[GMIA]. Gelatin Manufacturers Institute of America. 2013. Standard methods for the testing of edible gelatin. Offical procedure of the gelatin manufacturers institute of america. America.

Gunawan F, Suptijah P, Uju. 2017. Ekstraksi dan karakterisasi gelatin kulit ikan tenggiri (Scomberomorus commersonii) dari Provinsi Kepulauan Bangka Belitung. JPHPI 20(3): 568-581. 
Karim AA, Bhat R. 2009 Fish gelatin: properties, challenges, and prospects as an alternative to mammalian gelatins. Food Hydrocolloids. 23: 563-576.

Khirzin MH. 2016. Karakteristik Peptida Kolagen Teripang Gama (Stichopus variegatus) Sebagai Ingridien Potensial Pangan Fungsional Antihipertensi. [Tesis]. Bogor: Sekolah Pasca Sarjana. Institut Pertanian Bogor.

Leiwakabessy J, Mailissa RR, Simon PO, Leatemia. 2017. Komposisi kimia cacing kacang (Sipunculus nudus) di kabupaten raja ampat dan Kabupaten Manokwari. Jurnal Sumberdaya Akuatik Indopasifik. 1(1):53-66.

Nurilmala M. 2004. Kajian Potensi Limbah Tulang Ikan Keras (Teleostei) sebagai Sumber Gelatin dan Analisis Karakteristiknya. [Tesis] Bogor: Sekolah Pascasarjana IPB.

Nurilmala M, Wahyuni M , Wiratmaja H. 2006. Perbaikan nilai tambah limbah tulang ikan tuna ( Thunnus sp.) menjadi gelatin serta analisis fisika-kimia. Buletin Teknologi Hasil Perikanan IX(2): 22-33.

Pamungkas J. 2010. Sipuncula: Biota laut yang kontrovertif. Jurnal Oseana. 35 (1): 7-10.

Permata YW, Widiastri F, Sudaryanto $Y$, Anteng AA. 2016. Gelatin dari tulang ikan lele (Clarias batracus): pembuatan fengan metode asam, karakterisasi dan aplikasinya sebagai thickener pada industri sirup. Jurnal IImiah Widya Teknik. 15(2): 146-152.

Pertiwi M, Atma Y, Mustopa AZ, Maisarah R. 2018. Karakteristik fisik dank imia gelatin dari tulang ikan patin dengan pre-treatment asam sitrat. Jurnal Aplikasi Teknologi Pangan. 7(2): 83-91.

Rahayu R, Hudha AM, Sukarsono, Permana FH. 2019. Analysis of Nutritional Content of Fresh Sea Worm Honingka (Siphonosoma australeaustrale) as a Potential Food Source for
Communities. International Conference on Life Science and Technology 1-7.

Rapika, Zulfikar, dan Zumarni. 2016. Kualitas fisik gelatin hasil ekstraksi kulit sapi dengan lama perendaman dan konsentrasi asam klorida $(\mathrm{HCl})$ yang berbeda. Jurnal Peternakan. 13(1):26-32.

Said MI, Triatmojo S, Erwanto Y, Fudholi A, 2011. Karakteristik gelatin kulit kambing yang diproduksi melalui proses asam dan basa. AGRITECH 31(3): 190-200.

Sani RN, Nisa FC, Andriani RD, Maligan JM. 2014. Analisis rendemen dan skrining fitokimia ekstrak etanol mikro alga laut Tetraselmis chuii. J Pang Agr 2(2): 121-126.

Sasmitaloka KS, Miskiyah, Juniawati. 2017. Kajian potensi kulit sapi kering sebagai bahan dasar produksi gelatin halal. Buletin Peternakan 41(3): 328-337.

Silaban BB, Nanlohy EEEM. 2011. Profil nutrisi Sipuncula (cacing kacang): biota laut yang kontrovertif di pulau Nusalaut, Maluku Tengah. Jurnal TRITON 7(2):32-41.

Sopian I. 2002. Analisis Sifat Fisik, Kimia dan Fungsional Gelatin yang Diekstrak dari Kulit dan Tulang Pari. [Skripsi]. Bogor: Fakultas Pertanian IPB.

Suryati, Nasrul ZA, Meriatna, Suryani. 2015. Pembuatan dan Karakterisasi Gelatin dari Ceker Ayam dengan Proses Hidrolisis. Jurnal Teknologi Kimia Unimal 4 (2): 66-79.

Tourtellote, P. 1980. Gelatin. Di dalam McGraw Hill Encyclopedia of Science and Technology of Gelatin. Mc. Graw Hill Book Co. New York. 9394.

Trilaksani W, Nurilmala M, Setiawati IH. 2012. Ekstraksi gelatin kulit ikan kakap merah (Lutjanus sp.) dengan proses perlakuan asam. JPHPI 15(3):240-251. 
Wijaya OA, Surti T, Sumardianto. 2015. Pengaruh perendaman $\mathrm{NaOH}$ pada proses penghilangan lemak terhadap kualitas gelatin tulang ikan nila (Oreochromis niloticus). JPBHP 4(2):25-32.

Yang, H., Y. Wang, P. Zhou, and J. M. Regenstein. 2008. Effects of alkaline and acid pretreatment on the physical properties and nanostructures of the gelatin from channel catfish Skins. J Food Hydrocoll. 22: 1541-1550. 